Lisa Gaupp

\title{
12 How to Curate Diversity and Otherness in Global Performance Art
}

\author{
(Essay Together with an Interview with Claude Jansen)
}

Global performance art worlds are often presented as borderless and international. Through internationally active curators, their festivals and other cultural organizations, a global art market has developed which adheres to the motto of "diversity" (Peres da Silva \& Hondros, 2019) for increasing inclusivity. However, at the same time, global art worlds are criticized for being "too international” (Buț, 2017), and for standardizing an international canon which largely excludes, for example, "refugee" artists. So is diversity a "white word" (Cañas, 2017)?

The theoretical framework for this paper is formed by applying different postcolonial and transcultural perspectives to compare and criticize the application of different narratives of "diversity and otherness" in the field of global performance art. $^{216}$ This discussion will lead to an attempt to answer the research question of how diversity and otherness can be curated without labelling, paternalizing or exoticizing, i.e. by asking how curating can be decolonized, as structures and practices of neocolonialism, social inequality and exclusion persist on a global scale. This means that modes of transformation will be explored as forms of cultural expressions, which provide emancipatory views of cultural expression that are different from the hegemonic mainstream's entanglement with social inequalities.

The focus will lie on both the representation of diversity and otherness in the life-worlds of globally active performance art, music festivals and other cultural organizations, and the performativity of diversity and otherness in these fields of practice. While the former encompasses all structural conditions which influence how intersectional diversity and otherness are (re-)presented at festivals and other cultural organizations, the latter limits its attention to the practices and strategies of performing cross-cultural diversity and otherness as border-crossing. In other words, we shall take a look at how the concepts of intersectional and cross-cultural diversity and otherness are applied to the field of arts production, both in their symbolic uses in the

216 I have discussed the two narratives of diversity and otherness as intersectional and as cross-cultural in my other contribution in this volume as follows: Intersectional diversity encompasses intersecting social belongings which include, while intersectional otherness emphasizes these differences to exclude. Cross-cultural diversity describes ambiguous cultural symbols, cross-cultural otherness de-stabilizes differences. 
politics of representation (such as striving for equal access) and with regard to how border-crossing concepts are performed, negotiated and mediated in these fields.

Intersectional approaches to diversity and otherness in global performance art typically focus on unequal economic and power relations on a global scale and on ways of how to overcome these inequalities. In this connection, I will discuss approaches for increasing inclusion through strategies of intersectional diversity, as well as how practices of intersectional otherness often increase exclusionary outcomes in the arts. The intersectional approach thereby refers to multiple intersecting types of identity, which mutually influence other markers of difference. Cross-cultural notions of diversity and otherness in global performance art, conversely, brings into focus how ambiguous cultural symbols of entanglement, interconnectedness and spaces in-between are negotiated, standardized and deconstructed in the field of practice.

Such an approach entails focusing on the practice of doing and undoing differences (Hirschauer in this volume), by providing a genuinely praxeological stance (Reckwitz, 2005; Schatzki, 1996; Bourdieu, 1978). Even though the part of this chapter dedicated to intersectional strategies of representation places more emphasis on structures, while cross-cultural practices of performativity rather emphasize the actions of individuals and how the un-doing of differences is performed, both approaches rely on the common assumption of performative approaches (Butler, 2013; Bharucha, 2001; Fischer-Lichte, 2004; Fischer-Lichte \& Roselt, 2001; Goodman \& DeGay, 2000; Bial, 2004). The acting-out of narratives cannot be analysed without reference to the structures of the surrounding conditions, such as policies, finances, economy, organizational structures, etc. The same entanglement applies to how to theorize these performative practices, which depend equally on the construction of certain symbolic meanings as well as on the structuring conditions that are involved. Narratives are performed under specific conditions (Austin, 2014). So it is not only structure and agency that need to be thought about together (Archer, 2005), but idealist and materialist stances cannot be separated (Zembylas \& Niederauer, 2017).

This leads us to examine how curating is conceptualized in this chapter. Curating is a social practice embedded in a field of structures which enables as well as limits, and a social practice that combines the construction, performance and negotiation of situational meanings and their acting-out (Davida et al., 2019; Lind, 2012; Buden, 2012; Rugg \& Sedgwick, 2012). So Buurman et al. write:

To acknowledge both the structural constraints and the potentialities for agency, we suggest replacing theories of (fixed) identity with the notion of (changeable) positionality in relation to a number of intersecting and potentially shifting social affiliations (race, class, gender, age, location), ... to encourage casting aside the obsession with origins for one which is in favour of a perspective of practice and what one does, from being to doing, without forgetting that the options for agency are sometimes heavily confined and policed by outright violence, not to mention subtler mechanisms of discursive, social or biopolitical control. (2018, p. 20) 
With regard to methodology, this chapter is based on literature reviews. These academic studies will be complemented with my own empirical data from the field, as well as with some additional "good or bad practice examples". Empirical results which are included in this chapter are deduced from the qualitative expert interviews which I have conducted with 26 curators, dramaturges, artists and representatives of cultural organizations in globally active festivals and organizations of performance art and music in the period of 2014-2018. This chapter is largely based on an interview with Claude Jansen, an independent scholar, performer, dramaturge and curator from Hamburg. This interview served as a debate about the possibilities of decolonizing "curating performance art" on a global scale. How can dualisms and dichotomies of diversity and otherness be overcome, and how can practices of representations be transformed and set in a more contextualized relationship?

\subsection{Representation of Diversity and Otherness-An Intersectional}

\section{Approach}

Let us begin by taking a look at the fields of practice in global performance art and see how different academic studies look at social inequalities and multiple discriminations. It will also be necessary to exemplify notions of intersectional otherness and note how other approaches look at social inclusion from a perspective of intersectional diversity in these fields of cultural production. As stated in the introduction as well as in my other contribution to this volume, narratives that guide the area of intersectional diversity and otherness are mostly oriented towards the assumption that fields of global cultural production are interwoven with economical and power hierarchies. Social inequalities which result from processes of social determination are emphasized and intended to be overcome. Another important orientation is often the quest not only to unveil unequal power-relations but also to achieve greater equality and inclusivity within these cultural fields through, among other things, decolonization. Thus, differences between people or larger social groups are either emphasized in order to exclude outsiders from this group, or unity based on diversity is featured in order to include people with diverse and intersecting multiple identity-markers.

This leads us to social inequality as a further central concept of diversity in diversity studies which refers to the systematic access (or lack of access) to socially validated assets and resources, based on belonging to a social group determined by categorisations of gender, class, ethnicity or race, sexuality, religion or disability. (Jungwirth, 2019, p. 11)

When we look at the representation of diversity and otherness in globally active performing arts and music festivals and other cultural organizations, by entangling the structural conditions that influence how diversity and otherness are staged in these fields, we must consider how the terms and narratives of intersectional diversity and 
otherness are applied. Sara Ahmed has described how in diversity-work in universities, terms stemming from earlier feminism such as "equal opportunities" or "antiracism", which aspire to bear negative connotations by their confrontational and abundant use, have been replaced by the non-defined term of diversity "as a 'feel good' politics" (Ahmed, 2012, p. 69). "The shift from the language of equality to the language of diversity becomes linked to a shift from a confrontational to a collaborative working model, to sharing rather than enforcing values” (p. 64). For Ahmed, this use of the term has two sides. On the one hand, when diversity is used as such a "container term", the risk of obscuring inequalities (pp. 71-72) is apparent. On the other hand, the universal and plural possibilities of such a positive but non-defined term offers people the chance to fill it with their own content, and thereby "a community can take shape through the circulation of diversity. ... To speak the language of diversity is to participate in the creation of a world” (p. 81). In this light, is it possible to curate diversity and otherness in global performance art in an open-minded, non-hierarchical, postcolonial, anti-racist, transcultural and emancipated way? Even more importantly, how is this to be achieved? Is it possible to fill the concept of diversity in such a way? Does the term fulfil the promise of collaboration rather than confrontation?

The debate in global performance art is often concentrated on concepts such as participation, representation, access and inclusion (Gaupp, 2016). Questions that are raised in these contexts include, for example, how individuals can react to essentializing group identities and instead empower themselves, how cultural organizations can foster inclusivity without othering, and how institutionalized identity politics can avoid exclusion (Dobusch et al., 2020). For instance, suppose that one wants to create a more diverse audience for the audiences of art performances in Germany. The German debate particularly focuses on the participation of those citizens who have not so far been represented, especially young people and (young) immigrants, because the audience of tomorrow is not sufficiently reached by publicly funded culture. The established, publicly funded cultural institutions have therefore come under strong political pressure to prove their legitimacy. In particular after the socalled "refugee crisis" in 2015, these arguments can lead to the absurd situation, that, for example, in Berlin you can hardly find a refugee who has not been approached by at least three cultural institutions, asking if he or she wants to participate in a cultural project (Henze, 2017).

As I have shown in my PhD thesis (2016), the cultural policies concerning immigrant populations in Germany since the 1960s have mostly developed from the concepts of interculturalism, and multiculturalism. Intercultural or multicultural concepts of culture follow a traditional, nation-based concept of culture, and thereby foster differences between a homogenous "minority" and a homogenous "host society". Through this they construct and label their target group through markers of otherness, showing the mechanisms of “othering” or labelling (see also Köhl, 2001). 
This is also the case in some approaches of so-called intercultural audience development (Haberkorn, 2010; Mandel, 2014). Suppose, here, that one wants to include people in art performances who have hitherto been under-represented, by designing and implementing an agenda of diversity affirmation. Even though data shows that under-representation is prevalent (Horz, 2014) and that established power hierarchies which are often dominated by male white individuals hardly change at all, such an approach for, e.g., the target group "immigrants" runs into the danger of essentializing certain identity traits over others. The target groups can, for instance, become further differentiated in an intersectional manner. It also emphasizes the divide between "us" and "them" and thus fosters exclusion rather than inclusion.

A solid body of literature analyses the underlying reasons for exclusionary practices and under-representation in the arts concerning a variety of artistic genres, such as visual arts (see below), film (Dovey, 2015) and theatre (Heeg \& Hillmann, 2017). Scholarship has also previously focussed on the organizational side of implementing diversity in the arts, such as through cultural policies (Benzer, 2016; Sievers et al., 2018), audience research (Van Wel et al., 2006), community work (Pilić \& Wiederhold, 2015) and education (Lutz-Sterzenbach et al., 2013; Keuchel \& Kelb, 2015; Eremjan, 2016).

Many of these approaches apply postcolonial and/or poststructuralist theory to the field of interest, so again questions may be posed whether the outcome is really as it was theoretically intended-and in turn whether theory can learn from practice or is practice (Kolsteeg, 2019)-and how diversity and otherness can be curated without paternalizing and exoticizing. We will come back to these questions in the discussion.

Other examples do not obviously exhibit signs of exclusion, so the whole picture needs to be disentangled very carefully. An additional heuristic difficulty arises since diversity-sensitive and cross-cultural concepts, as well as transcultural and postcolonial theory, have become a major ingredient for many global arts organizations today (Do Mar Castro Varela \& Haghighat, 2020). How, then, should we conduct theory when within a single cultural field the same concepts, such as academic postcolonial and poststructuralist critique, are being applied? Or to put the question differently: "What contribution can deconstructive readings and highly abstract conceptualizations make to the real liberation struggles from neo-colonial exploitation of the Global South?"217 (Angermüller \& Bellina, 2012, p. 34). For Johannes Angermüller and Leonie Bellina, this task can only be achieved by consequently bringing together theory and practice. Equally, Alexandra Karentzos suggests taking into account different levels that all need to be addressed simultaneously. Regarding the enforcement of a "postcolonial art history", it is not sufficient to apply postcolonial critiques to exclusionary

217 "Welchen Beitrag können dekonstruktive Lektüren und hochabstrakte Begriffsbildungen zu realen Befreiungskämpfen gegen neo-koloniale Ausbeutung des Globalen Südens leisten?” (Angermüller \& Bellina, 2012, p. 34). 
practices such as (re-)establishing hegemonies by curating certain objects as "other objects". An example of the latter is the exhibition Primitivism in $20^{\text {th }}$ Century Art at the Museum of Modern Art in New York in 1984, which opposed European "masters of modernity" to the "traditional Other" (Karentzos, 2012, p. 250). Also, on an academic level, art history needs to be revised in order to deconstruct the established construction of "ethnic encoding of an artist" in academia. Thirdly, contemporary art practices which challenge these exclusionary practices of otherness in the museum, by offering a transdisciplinary view from combined art-historical, anthropological and artistic perspectives, in order to set a "transcultural polyphony" against those "linear master narratives” (p. 253), are in need of being critically re-considered. Such "postcolonial streams in contemporary art challenge art-scholars to rethink their own theory formation in a postcolonial manner"218 (p. 249). Thus, this approach suggests simultaneously a decolonizing of practice and academia by including plural and transdisciplinary voices.

However, with such an approach, other difficulties can arise. The more people participate in, for example, curating processes, the more differentiated (political) agendas need to be negotiated in order to reach a common goal. These agendas can be more or less individual, ${ }^{219}$ such as by adherence to a certain artistic understanding, or they can be related to group identity politics, such as wanting to increase the representation of a certain social group. For instance, in a transnational, collaborative project between German and “African” artists,

you actually have two positions, on the one hand the diasporic, progressive one [in Germany] which wants to untangle that [Africa is not a country ... not the continent of illusions with all its fantasies] from a position that I find absolutely correct. ... But [on the other hand,] in African countries I know a lot of artists coming from a very strong political context, who speak more radically of the continent [in reference to the pan-African idea ... in order to not acknowledge the national, colonial borders]. ${ }^{220}$ (Jansen, personal communication, October 17, 2018)

218 "postkoloniale Strömungen zeitgenössischer Kunst [stellen auch] eine Herausforderung für die Kunstwissenschaft dar, die eigene Theoriebildung postkolonial weiterzudenken” (Jansen, personal communication, October 17, 2018).

219 However, the majority of the academic approaches in this area regard the cultural field (Bourdieu, 1993) or the art world (Becker, 2008) not as an individual task but rather as a social endevour. Thus, they can be related to the Sociology of Culture by also looking at the actions of individuals as stemming mainly from the social position of an individual and his or her relationships.

220 "in Referenz zur panafrikanistischen Idee, die ja vor 100 Jahren als erste, entsprechend der Verhandlungen mit den Partnerinnen und Partnern aus dem jeweiligen Land und es nach diesen Ideen gibt. Und das es eben viele meiner Co-Produktionspartnerinnen aus den Ländern sagen, dass sie die nationalen, kolonialen Grenzen nicht anerkennen und deswegen, eigentlich, aus ihrer Position, erneut von Afrika als einen Kontinent sprechen. Wobei und da haben wir schon den ersten Graben zu der Diaspora, die natürlich sehr stark auf ,Africa is not a country', eben sehr stark, in den Schulungsprozessen der EuropäerInnen darauf verweist, dass es eben viele Länder gibt und Afrika ist nicht der Illusionskontinent, mit all den Fantasien und so. Und da geht es eigentlich schon los: 
In addition, both positions are situationally even more split up. The "German side" can be influenced heterogeneously by, among other factors, funding schemes and/ or postcolonial theory, which "want to dissolve the African cliché, in Germany" by including migrant Afro-Germans into the project, "whereas the African says, your clichés are of no interest to me"221. Furthermore, the "African" positions "already differ very vehemently among each other between Namibia and South Africa” (Jansen, personal communication, October 17, 2018). Likewise, "a great many positions come in" 222 (Jansen, personal communication, October 17, 2018). Thus, such an intersectional diversity of voices can both offer emancipatory views and foster intersectional otherness, by emphasizing the differences between all perspectives.

As stated above, there are numerous examples of academic studies which analyse the power-relations in different fields of global arts, which foster exclusion rather than inclusion. A large majority of these approaches to intersectional otherness in global cultural production is focused on the visual arts. In particular, the debates around the establishment of the Humboldt-Forum in the centre of Berlin, as a space for the display of "the cultures of the world" (Stiftung Humboldt Forum im Berliner Schloss, n.d.; Di Blasi, 2019), the decolonizing of more traditional anthropological museums, such as the former Museum für Völkerkunde Hamburg which has been transformed into the MARKK Hamburg (https://markk-hamburg.de; Kraus \& Noack, 2015), post-colonially oriented biennales such as documenta $\mathrm{XI}^{223}$ (2002 in Kassel) and the topic of colonial and Nazi-looted art and their restitution, have sparked considerable attention in several academic disciplines within art history (Rother, 2017; Macdonald, 1996). Other authors focus on "outsider art" (Zolberg \& Cherbo, 1997) from under-represented visual artists, such as "primitive African art” (Zolberg, 1997), or on the power hierarchies in the visual arts (Below \& von Bismarck, 2005; Behnke et al. 2015; Buchholz \& Wuggenig, 2005 224).

dann hast du eigentlich zwei Positionen, nämlich zum einen die diasporische, aufklärerische, die das aufdröseln möchte, aus einer Position, die ich absolut richtig finde, einerseits. Aber wie gesagt, in den afrikanischen Ländern kenne ich sehr viele Künstlerinnen und Künstler die aus einem sehr starken politischen Zusammenhang kommen, die viel radikaler wieder von Kontinent sprechen” (Jansen, personal communication, October 17, 2018).

221 "Wobei [diese Seite] ja das afrikanische Klischee auflösen will, in Deutschland. Während die Afrikanerin sagt, Was interessieren mich eure Klischees?” (Jansen, personal communication, October 17, 2018).

222 "Und da kommen dann noch einmal zig Positionen rein. ... Und die unterschieden sich ja schon vehement von Namibia zu Südafrika” (Jansen, personal communication, October 17, 2018).

223 This was curated by the first non-European curator Okwui Enwezor, who laid open the "asymmetry between curating and curated cultures" by citing Gerardo Mosquera in the documenta catalogue (Enwezor, 2002, p. 46; see Mosquera, 1994, as cited in Karentzos, 2012, p. 251).

224 The manifold relation between all kinds of art genres and power is the subject of another volume entitled "Arts and Power - Policies in and by the Arts", which I am editing, to be published in 2021 by Springer VS Gaupp et al., 2021). 
Thanks to such critique, in the field of practice, new identity politics and interest groups, such as the Initiative Bündnis kritischer Kulturpraktiker_innen (https:// mindthetrapberlin.wordpress.com) or the Diversity Arts Culture (http://www.diversity-arts-culture.berlin/en), have been developed. Both of these organizations host conferences and cultural events which are intended not to reproduce the mentioned exclusions. In order to protest against racist and extremist right-wing attacks on cultural organizations and artists in Germany, the association DIE VIELEN was founded in 2017 and published the declaration Wir sind Viele, ${ }^{225}$ besides organizing a large array of events such as anti-racist lectures and discussions ${ }^{226}$ (http://theaterderwelt2017.iti-germany.de). Elsewhere, others also criticize these exclusionary outcomes of such diversity-affirmative actions, but still see the need to follow such an agenda in the medium term, in order to change the hierarchical and neo-colonial structures of the cultural field in the long-run (https://www.kiwit.org/kultur-oeffnet-welten/ kultur-oeffnet-welten.html).

One study by the global media company Pitchfork on diversity, which was concerned with the line-ups of major popular multi-genre music festivals in the US and Canada, shows that the same groups and artists tended to play at these festivals in 2017, and that these artists came mainly from European countries or at least were based in the so-called "West". (Pitchfork, n.d.) This study also showed that there is a homogeneity in the American and Canadian festival scene regarding gender balance and other diversity markers, "especially toward the top of the bill” (Bishop, 2018). These findings are no different if we take a look at the programmes of publicly funded festivals in Europe. The same groups and artists are playing at these festivals, and they are mainly artists from European countries or at least based in the so-called "West".

When it comes to these issues of representation, one also has to take into account structural conditions, such as the financing strategies of the festival producers themselves. For example, to keep costs down, festivals form networks to co-produce new productions. This practical strategy has consequences for diversity, as it contributes to having the same groups booked at a majority of these festivals in the "Western" world (Gaupp, 2020). Another very influential issue concerns visa permits, which sometimes prevent musicians from certain countries touring or travelling at all. Even if a record company manages to bring artists to Germany to record, other problems can arise when it comes to paying royalties to the musicians, since not every country has a royalty association, such as the GEMA in Germany (Record label representative, personal communication, May 3, 2018). For this reason, one could think that these networks, visa conditions and royalties would result in a closed circle of a kind of

225 We are Many.

226 At the end of 2019, nearly 3500 cultural organizations and persons working in the field, coming from 16 cities and regions and 15 German federal states, have signed the declaration and participated in the organization of such events. 
"Western male white canon in global arts". However, in an interview I conducted with a curator, she stated that sometimes these networks are a very good way for unknown artists to become produced on an international level. After all, it only takes one of the curator gatekeepers to be convinced in order for a work to be produced. Moreover, once an artist is a part of the bigger and more established festivals, they will be more willing to feature the same artist (Gaupp, 2020).

But there is still a nationalistic focus in this process. One curator expresses this aptly when she states that-mainly due to the financial crisis-national funding bodies tend to focus on resident artists only (Kaup-Hasler, 2012). After all,

in a field of cosmopolitan self-conception, territorial or rather national criteria still are meaningful regardless of their rejection. Artists without north-Western geographic origin are still underrepresented in the centre of the art field where actors with high field-specific symbolic recognition prevail. ... Field theory offers explanations for these facts by looking at the institutional structure of the art field, i.e. the distribution of relevant resources. ${ }^{227}$ (Buchholz \& Wuggenig, 2012, p. 179)

Fewer approaches appear to discuss how inclusion can be achieved in cultural organizations, which follow an approach of intersectional diversity and/or focus on other artistic genres besides the visual arts. For instance, Johan Kolsteeg has published some studies on the strategies of inclusivity in a Dutch theatre, and has shown that a complex process needs to take into account not only the structure of the organization itself (for instance, by implementing flexible management structures or rotating project leadership) and a carefully designed audience development strategy (by focussing on e.g. a “delta of niches”), but also to think of the cultural organization's stakeholders (by including plural collaborations with local and regional partners) as well as developing a talent development strategy (e.g. by connecting the local to the global) (Kolsteeg, 2019). Only by taking into account all of these levels (and probably more, in other contexts), by establishing Richard Sennetts' social triangle (2003) of authority, cooperation and trust, can social entrepreneurship in a cultural organization be achieved, which accounts for inclusivity as a starting point of cultural democracy (Kolsteeg, 2019).

For example, many performing art festivals organized by politically active or at least engaged organizations are trying to achieve a gender balance within their artists' roster. The Festival Theater der Welt at Kampnagel 2017 in Hamburg discussed these topics around discrimination processes (http://theaterderwelt2017.iti-germany.

227 "Territoriale bzw. nationale Kriterien haben ungeachtet ihrer Zurückweisung in einem Feld mit kosmopolitischem Selbstverständnis offenbar nach wie vor Bedeutung. Künstler/innen, die nicht auf eine nordwestliche geografische Herkunft zurückblicken, sind in jedem Zentrum des Kunstfeldes nach wie vor schwach vertreten, in dem sich die Akteure mit hoher feldspezifischer symbolischer Anerkennung konzentrieren. ... aus feldtheoretischer Perspektive [gibt es hierfür] Gründe ..., die nicht zuletzt in der institutionellen Struktur des sozialen Systems der Kunst zu suchen sind, d. h. in der Verteilung relevanter Ressourcen” (Buchholz \& Wuggenig, 2012, p. 179). 
de). Another example is taken from the music industry and is called the Keychange Initiative, which was granted 1.4 million Euro of the EU's Creative Europe funding scheme in October 2019 at the Reeperbahn festival in Hamburg. The initiative seeks to achieve a 50:50 gender balance in the industry by 2022, through activities such as supporting female artists and innovators with cross border collaborations and showcases, engaging more festivals in the 50:50 gender balance pledge, raising awareness and stimulating debate in events and panel discussions, and establishing female role models through Ambassadors and Inspiration Awards (https://keychange.eu).

Moreover, cultural policies are also seeking to increase intersectional diversity and thereby building a more inclusive society, by following the Creative Justice Model of access, diversity, inclusion, equity (Cuyler, 2019). In this regard, J. P. Singh distinguishes between four different international discourses in cultural policies, which operate in the grey area between consensus and conflict. Accordingly, consensus can be reached on a nation-state level either through hierarchical structuring or horizontally via different actors. More conflict-oriented discourses are rather found to stem from social pressures, either by mobilizing discourses of social movements or by counter-discourses of, for example, community projects (Singh, 2019). Can these examples show the way to support intersectional diversity in the global arts and decolonize unequal power structures? We will come back to these and other possibilities to decolonizing global curating and to curating diversity instead of otherness later in the discussion.

\subsection{The Performativity of Diversity and Otherness-A Cross-Cultural}

\section{Approach}

Let us now turn to the concepts of cross-cultural diversity and otherness and examine how these concepts are applied in the field of practice of performance art. To this end, we will focus on the performativity of diversity and otherness, speaking of the practices and strategies of performing diversity and otherness in a cross-cultural way. While the previous section, which was devoted to the representation of intersectional diversity and otherness in the arts, focussed chiefly on individuals or groups, this section will concentrate on the aesthetic art forms, and especially on how artistic practices are performed. These practices are presented as border-crossing and crosscultural, which means that they are either attributed to no pure genre or origin but are rather global and/or hybrid (Davida, 2011), or that they open up possibilities of in-between-spaces and re-readings of established (b-)ordering practices.

Likewise, these performativities of diversity and otherness can also be called diversity in the arts, aesthetic diversity, or the diversity of cultural expressions, as it has been defined in (e.g.) the 2005 UNESCO Convention on the Protection and Promotion of the Diversity of Cultural Expressions (UNESCO, 2013). According to this 
convention, the central goal is to increase the visibility of global artistic diversity. Cultural diversity, in the case of the UNESCO convention, strives for no less than worldwide peace, and in the convention one can read that: "Cultural diversity, flourishing within a framework of democracy, tolerance, social justice and mutual respect between peoples and cultures, is indispensable for peace and security at the local, national and international levels" (UNESCO, 2013, p. 3). As I will show, this remains one of the most challenging tasks in global art worlds. The UNESCO convention was founded to oppose the further liberalization of the global market for cultural goods and the market domination of the USA in the 1980s. Connected to these developments are discourses around the potential of cultural expressions for social transformation (Lettau \& Knoblich, 2017; Kagan 2011), as well as peace-building activities through cultural policies (UNESCO, 2013; Schneider \& Gad, 2014). However, for Singh, these cultural policies led by UNESCO should be criticized as protectionist, as they and further international regulations privilege national identity constructions, which are themselves used by post-colonial interest groups in their fight for indigenous rights (Singh, 2019; Pelillo-Hestermeyer in this volume).

Another example of the contradictory outcomes of cross-cultural agendas is the National Festival for Iranian Folk Music, which I was invited to attend for the purposes of field research in 2017. This festival takes place nationwide, and is organized by the government through the Iranian Music Council. It focuses exclusively on the genre of folk music, but in practice an enormous cross-cultural diversity of instruments, folk music styles, idioms, languages, dress, etc. is found there, which in turn supports national unity based on artistic diversity.

This artistic diversity not only means a variety of aesthetic styles, but can also include intermedial diversity (i.e. the use of different artistic media within one performance; Rajewsky, 2002) or inter-art diversity (i.e. the use of different art genres or the crossing of art genres boundaries within one performance; Bharucha, 2001). As this first kind of intermedial diversity is not the precise focus of this study, we can turn directly to look at inter-art diversity instead. The focus of the empirical study which I carried out lies on the "genre" performance art in general, and specifically on music understood as any kind of sound practice in the broadest sense (Small, 2010). In addition, considering my research focus on diversity, performance art offers a highly appropriate research field, as it includes a diversity of art genres and categories:

Historically, performance art has been a medium that challenges and violates borders between disciplines and genders, between private and public, between everyday life and art, and that follows no rules. In process, it has energised and affected other disciplines-architecture as event, theatre as image, photography as performance. (Fischer-Lichte \& Roselt, 2001, p. 241)

Another, but very similar, approach focuses on the arts in general or art festivals with specific regard to this organizational format. Many curators come to biennales such as the documenta, in order to find "new" artists who are able or willing to cross artistic 
genres, such as in the case of the visual video artist Wael Shawky, who produced a performance on the theatre stage at the festival Theater der Welt 2017 in Hamburg (http:// theaterderwelt2017.iti-germany.de). His stage-setting is a visual piece of art in itself, which is surrounded by and embedded within music, drama and dance elements.

Nevertheless, music is still the focus of my research. For example, I have asked the curators why they would include music in their programme. There are many answers to this question. In most theatre and dance performances the musical layer is extremely prominent by default. This is why music is important to a curator I interviewed. For the purposes of staging pure music concerts, more specialized institutions in town are typically able to complete this task more successfully (Two festival curators, personal communication, May 26, 2015). Another performance art festival was founded as a music festival, and only later did it include more theatre and dance performances into its programme, still retaining a large music programme (Festival curator, personal communication, May 28, 2015). Yet another festival presents a large popular music programme at nights for "socializing" and the "enjoyment" of the audience (Festival curator, personal communication, June 17, 2015). Also in the same city, there is another performing art festival with a focus on contemporary music rather than theatre or dance performances, with the intention of not being a direct competitor of the other performance art festivals or dance festivals which are now established in town (Festival curator, personal communication, June 14, 2015).

As we can see, on the level of inter-art diversity, the practices in performance art seem to foster cross-cultural diversity, as genre barriers become dissolved, and a wide variety of artistic approaches are included in these festivals. However, when looking more closely at the differences between different kinds of genre in the eyes of curators, certain practices of cross-cultural otherness seem to be prevalent. For example, the genre of music ${ }^{228}$ is slightly discriminated against when it is described as a "easy to consume" genre, in contrast to a "more intellectually challenging theatre performance”. Of course there are many more reasons for such a curational approach, but in sum artistic genre boundaries are dissolved rather than enforced, given the crossgenre approach of performance art in general.

In performance studies a shift to "the global" can be detected, thus situating performance art within the "mobility, transnational and global turns" (see my other contribution in this volume). In other artistic genres, such a focus on "global arts" is also evident. Furthermore, there is an ongoing genre-crossing debate on translation (Apter, 2013), on migratory aesthetics (Durrant, 2007), on the (im-)possibility of defining "an African contemporary dance aesthetic" (Douglas et al., 2006) and on the

228 How musical genres are constructed in the first place and how genres serve to stabilise and destabilise communities is the subject of a wide corpus of sociological literature, that can be assigned mainly to the field of sociology of music. See, for example, Lena, 2019. 
de-territorialisation of art (Dorn, 2004), which also belongs to the debate about crosscultural diversity and otherness in the arts.

For instance, in literary studies, debate has recently focussed on the concept of "world literature" in light of globalization (Thomsen, 2008). Introduced by Johann Wolfgang Goethe in 1827, this term is as un-definable and contested as is, for example, "world music", which has been heavily criticized for its Eurocentric notions (Krüger, 2013; Peres da Silva, 2017). For Mads Rosendahl Thomsen, the more recent shift to the "global" highlights the point that it "will always be a world literature as seen from a particular place, even though some aspects are shared” (Rosendahl Thomsen, 2008, p. 1). He therefore looks at the processes of how certain kinds of literature become canonical on an international scale. ${ }^{229}$ In this light, "world literature" can never be as universal as the term suggests.

It is with this in mind that Emily Apter and her colleagues focus on the "untranslatability of languages" (Cassin \& Apter, 2014). Other scholars give attention to hybrid, transcultural and interweaving forms of literature (Hitzke, 2019) or seek to re-write "European Peripheries in the Postcolonial Literary Imagination" (Hauthal \& Toivanen, 2021). Likewise, Ottmar Ette prefers the term "literatures of the world", which acknowledges the "vectorisation of all references"230 (Ette, 2017, p. 59). One of the research foci of the renowned Leibniz-Zentrum für Literatur- und Kulturforschung in Berlin is also named "world literature", which demonstrates a similar critical approach that takes into account the fact that "world literature refers to the specific global conditions shaping the realm of literature and to the effects globalisation has had on literary production and its reception in a rapidly changing society" (https://www.zfl-berlin.org/world-literature.html). These approaches thus mirror the epistemological development of a cross-cultural view of the diversities and otherness of literature, by focussing on the entanglements of post-colonial writings.

Similarly, in the field of the visual arts, the notion of contemporaneity has been deconstructed (Osborne, 2013; Smith et al., 2009) and unmasked as deeply Eurocentric, on the grounds that it is often set in opposition to "non-Western" art forms, to which certain traits of traditionality are often ascribed (Dornhof et al., 2018; Horst \& Schwartz, 2012). In fact, the two sides of cross-cultural diversity and cross-cultural otherness are often present in such approaches at the same time. When, for instance, the othering mechanisms which continue to prevail in art history are sought to be decolonized (Allerstorfer \& Leisch-Kiesl, 2017), the movement of deconstructing hegemonic border demarcations shows the notion of cross-cultural otherness at play. When instead the focus lies more on how visual art forms and practices are themselves

229 This question is treated by, among others, But (2017) in the field of visual arts, who shows that an international canon has developed which is "too international", excluding a wide variety of cultural expressions.

230 “Vektorisierung aller Bezüge” (Ette, 2017, p. 59). 
presented as entangled and cross-cultural (Seliger, 2011), we can speak of strategies of cross-cultural diversity. This means "look[ing] at (global) art from a transcultural perspective that acknowledges the inherent transculturality of artistic practices and artefacts, [along with their] dynamic cross-cultural constellations, migrations and transformations, locations and dislocations” (Buurman et al., 2018, p. 17).

Thus, the focus of the cross-cultural entanglement is also present in visual art scholarship. However,

in the methodical descriptions of entangled histories, what has remained unanswered is how this entanglement is constituted, who the actors are, on which levels societies, cultures etc. are entangled, and based on which subjects, objects and concepts these stories can be related. (Leeb, 2015, p. 211)

In this connection Susanne Leeb describes how "postcolonial narrations" have influenced art history. According to her, these "increasing approaches toward a transnational art historiography in the past years have made very little impact on the level of museum presentations" (Leeb, 2015, p. 214). What is at stake here is the strong connection of the concept of cross-cultural diversity with intersectional diversity, as discussed above. On the one hand, visual art forms that challenge the Eurocentric meta-narrative by including entangled, transcultural notions are increasingly presented as "entangled-global-but contextual". On the other hand, the quest to decolonize museums, to achieve a greater representation of those cross-cultural art forms and artists from the "Global South" within canonical museums, and to overcome the established divide between "fine arts" and "ethnic culture" is striven for. Museums are increasingly bound to curate "non-Western" artists and postcolonial topics, as well as to call established curatorial practices into question. For instance, the abovementioned former Museum für Völkerkunde Hamburg (Ethnological museum) has been renamed the MARKK-Museum am Rothenbaum-Kulturen und Künste der Welt (Museum at Rothenbaum-Cultures and Arts of the World) in 2018, under the leadership of its new director, Barbara Plankensteiner, who has started an extensive reform on the aforementioned premises. Together with my co-authors I have shown in another empirical mixed-method study that, while the new self-image of the MARKK has already been implemented, the exhibitions still need further development to ensure that the content reaches visitors (Gaupp et al., 2020). We have also shown how, in the case of different museums and events, e.g. the Venice Biennale, the intended focus on postcolonial issues and the desire for greater representation of Artists of Colour for example, can indeed increase cross-cultural diversity in visual arts. However, the same intention can also lead to intersectional otherness, when only Artists of Colour are curated for those postcolonial topics, whereby they function as tokens without really challenging the structures of unequal representation and power relations.

Furthermore, in the field of music, similar approaches can be detected. The debate on deconstructing "world music" as Eurocentric (Guilbault, 1997), the quest 
to conceptualize music practices as inherently border-crossing (Peres da Silva \& Hondros, 2019; Sardinha \& Campos, 2016; Kim \& Riva, 2014) and the bid to achieve greater visibility for globally underrepresented musical expressions (Beyer \& Burkhalter, 2012; Beyer et al., 2015), by focusing on a "decolonial turn" in (ethno-) musicology ${ }^{231}$,can be related to both the practices of cross-cultural diversity and cross-cultural otherness. Again, notions of intersectional diversity and otherness are interwoven with those same practices (Alisch et al., 2018). An example of this would be the web space NORIENT, which wants to act as "an advocate for music scenes from Bolivia to Ghana to Pakistan-and for a world beyond Eurocentrism, exoticism and discrimination" (https://www.startnext.com/en/norient).

Finally, focusing on the more conspicuously genre-crossing field of performance art, similar debates have influenced the theatre sector. The academic narrative has shifted from "intercultural theatre" (Shevtsova, 2009) to "transcultural theatre" (Heeg, 2017) on the level of the theatre texts and performances, i.e. artistic practices. Intersectional otherness in turn is present in many approaches to increase representation, for instance of "immigrant theatre" (Shevtsova, 2009) and the evolvement of the "postmigrant ${ }^{232}$ theatre" movement in Berlin (Haakh, 2015; Sharifi, 2011). In 2008, Shermin Langhoff founded the theatre space Ballhaus Naunynstraße in Berlin-Kreuzberg as a "postmigrant theatre" with the intention to avoid focus on ethnic ascriptions and to increase participation of immigrants in the art scene (http://www. ballhausnaunynstrasse.de). Since then, the concept of postmigrant theatre and Langhoff herself has gained an enhanced reputation, for instance by receiving the most highly endowed Kairos Cultural Award in 2011 (Alfred Toepfer Stiftung, n.d.) or by her appointment as artistic director of the prestigious Maxim Gorki Theatre Berlin in 2013 (Maxim Gorki Theatre Berlin, n.d.).

Another prominent approach is the concept of "Interweaving Performance Cultures" (Fischer-Lichte et al., 2014). As Fischer-Lichte writes, "[h]ere, moving within and between cultures is celebrated as a state of in-betweenness that will change

231 In the years 2019 and 2020, several musicological conferences focus on topics of decoloniality, for instance the research colloquium on "Sound / Music / Decoloniality" at Maynooth University in March 2020, the symposium on "Decolonising of Knowledges" at University of Music and Performing Arts Vienna in May 2019 and the symposium on "Decolonizing Europe through Music Scholarship?" at the International Congress of the German Musicological Society in September 2021 in Bonn.

232 The term "postmigrant" with regard to postmigrant society was coined by Naika Foroutan in 2012 and describes "not a finished process of migration but an analytical perspective that deals with the conflicts, processes of identity formation, and social and political transformation which have started after migration and after the recognition [of Germany] as a country of migration." "Postmigrantisch steht ... nicht für einen Prozess der beendeten Migration, sondern für eine Analyseperspektive, die sich mit den Konflikten, Identitätsbildungsprozessen, sozialen und politischen Transformationen auseinandersetzt, die nach erfolgter Migration und nach der Anerkennung, ein Migrationsland geworden zu sein, einsetzen" (Foroutan, 2016, p. 232). 
spaces, disciplines, and the subject as well as her/his body in a way that exceeds what is currently imaginable” (Fischer-Lichte, 2014, p. 12). For this group of scholars, who have conceptualized performances as inherently interweaving, cross-cultural also describes a focus on the (historical) entanglements of drama. By going beyond postcolonial theory and employing concepts such as double criticism (Khatibi, 1985), Khālid Amīn and Mohammed Laamiri seek to find a different way, by asking: "Do we have to consider hybridity as the ultimate and inexorable condition of all postcolonial subjectivities? Or shall we think of it as a road map leading to alternative exchanges?” (Amīn \& Laamiri, 2010, p. 7).

The utopian aspects, which are often connected with such a deconstructed meaning of diversity (or, in these cases, named interweaving cultures and hybridity) have to be critically approached. First, the critique towards concepts of cross-cultural diversity, which neglect existing social inequalities and unequal power relations by celebrating and consuming diversity, needs to be taken into account. Such inequalities will not become smaller purely through an increase in the number of interweaving performances. In addition, it needs to be clarified-especially in times when the US government, under the leadership of the President Donald Trump, presents lies as "alternative facts" (Moore, 2017) - what "alternative” means, i.e. alternative to what? (Bachmann-Medick, 2016) The positionality of all these concepts should be laid open in order not to present merely another dichotomy of "the West versus the rest" (Hall, 1994).

What can be summarized at this point is that, in all discussed artistic genres, similar debates have evolved which centre on practices which cross or are intended to cross (dichotomous) borders (genre, national/regional, ethnic, etc.) and foster spaces-in-between instead. Often these quests become entangled with notions of intersectional diversity and otherness, when not only the art practices but also the representation of artists, curators, audiences, etc. come into focus. Last but not least, such cross-cultural, border-crossing practices can at the same time construct new orders, which might be themselves declared as universal or result in other exclusionary practices again.

Focusing on the transcultural topologies of global art thus permits the study of relational processes of circulation and exchange while also calling into question the idea of ethno-cultural locality as a nostalgic marker of authenticity as well as celebrations of multicultural plurality that disregard ongoing inequalities in capitalist and (neo-)colonial power relations. (Buurman et al., 2018, p. 18)

Thus, when we look at practices of cross-cultural diversity and otherness in the arts, the arts are either conceptualized as "global" and border-crossing or as situational, so as to require some kind of translation in order to foster inclusivity on a global scale (Apter, 2013; Dätsch, 2018; Charle et al., 2017; Klein, 2013). While the former approach relies on a concept of culture which is conceived as transcultural and dynamic per se, lacking in any pure origin (Stroh, 2005), the latter negates the fact that the arts can 
function as a "global language" (Binas-Preisendörfer, 2008), which is understandable globally, though differently appropriated. It rather follows a concept of culture which sets culture as socially transmitted, internalized, situationally performed (Dorn, 2004) and understandable only to members of a specific art world (Becker, 2008) or cultural field (Bourdieu, 1993).

These two opposing regimes have been pointedly summarized by Grace Brockington in relation to a dispute between Selwyn Image and Lewis F. Day at the beginning of the $20^{\text {th }}$ century (Brockington, 2009). While for Image, art is locally or nationally embedded, it is "particular. Far from being a universal language, it is locally produced and historically conditioned, the individual expression of an artist, or ... of a nation" (Brockington, 2009, p. 1). It cannot fully be translated (Gaupp, 2018). However, Brockington states how Day takes the opposite view and rather tends towards the concept of cosmopolitan artists. "National traditions are innate but not homogeneous and do not need to be 'coddled.' The English are a 'mixed lot', a hybrid race, practicing a hybrid art” (Brockington, 2009, p. 2). In this dichotomy of conceptualizing cultural expressions, both cross-cultural diversity and otherness can be detected. While the particular, situational view on the diversity of artistic expressions can be related to the narrative of cross-cultural otherness, the latter concept, which portrays the arts as hybrid and cosmopolitan, can be described as an approach to cross-cultural diversity. Nevertheless, this debate is mainly situated on the level of narratives, while in this contribution we intend to look at how these concepts are applied in the field of practice.

Here, the picture becomes even more complicated and blurred. The majority of artists whom I spoke to conceptualize their artistic practices as transcultural rather than as connected to a certain geographic region (Two artists, personal communication, May 5, 2015). Art and diversity both appear to be a dynamic process that cannot be defined in any a priori sense. Their artistic practices are characterized by crossing borders, by connecting to many people with many world-views, thus producing seemingly perfect cross-cultural practices. For instance, the art space in Berlin and founded in 2009 by Bonaventure Soh Bejeng Ndikung "S A V V Y Contemporary, situates itself at the threshold of notions and constructs of the West and non-West, in order to understand and negotiate between, and thereby deconstruct, the ideologies and connotations eminent to such constructs" (SAVVY Contemporary, p. 1). Another example in performance art which seeks to decolonize the art field and thereby increase both intersectional and cross-cultural diversity is the Migrantpolitan at Kampnagel in Hamburg, which curated by among others Anas Aboura. Kampnagel describes this as:

a campaigning space ... where diasporic and local artists enter into a process of exchange, develop joint transcultural strategies, and test out new forms of aesthetic praxis. This microcosmos is a laboratory for collaboration under conditions of solidarity, where new ideas can 
be developed, where cultural self-determination has a home, and where a pinch of anarchy is always part of the mix. (Kampnagel, 2019)

For some artists themselves as well as audiences and curators, these and other practices of performing cross-cultural diversity are evident. Sociological research in the arts has shown extensively how interpretation is an individual and intrinsically social matter (Abbing, 2019). This means that the interpretation of symbolic meanings which are ascribed to certain artistic expressions by the artists themselves might not necessarily perceived in the same manner by the audiences. For instance, an artist whom I interviewed described himself as cosmopolitan (Artist, personal communication, January 9, 2015), while the same artist was labelled a "typically Middle-Eastern artist" by a curator (Curator, personal communication, January 22, 2015). Marketing experts, media representatives and audience members also have different approaches in how to present and perceive this artist(ic expression) (Festival curator, personal communication, May 28, 2015). As a result, transcultural or cross-cultural art forms do not exist per se-or, any artistic practice would need to be called cross-cultural, assuming the arts' dynamic and processual character. But certainly, an artist or art form can be constructed and perceived as cross-cultural. It may rather be only that this construction has less to do with the actual artistic content than with its situational use.

This situational semantics offers two different perspectives in how to curate diversity and otherness. The first is to acknowledge that labelling is a dynamic and thus influenceable, changeable process, and certain wording and concepts can be used strategically and/or negotiated every time anew. "Performance is ... the joint execution in a (specific) situation. ... It is not to be determined and not to be understood, (the execution is only) at the moment”233 (Jansen, personal communication, October 17, 2018).

The second reading relates to an analysis of power inequalities in these negotiation processes. Those with more power have greater opportunities for defining the norm, and for standardizing certain interpretations over others. This leads us to the overarching question of how to decolonize the field of performance art without essentializing just another hegemonic norm. This will be discussed in the next section.

233 "Performance ist ... der gemeinsame Vollzug in der Situation. ... Der ist nicht zu determinieren, und der ist nicht zu verstehen, der ist im Moment" (Jansen, personal communication, October 17, 2018). 


\subsection{How to Curate Diversity and Otherness-The Decolonization of}

\section{Curating}

As I have pointed out in my other chapter on epistemologies, the quest to decolonize is called for in several life-worlds and can be traced back to the political decolonization and liberation processes in the 1950s, which spurred the academic stream of postcolonial thinking. This stream of thinking called not only for political liberation from colonial structures but also wider cultural and epistemic decolonization. Transferred to the present day, this task continues to be relevant, as dichotomies in thinking persist. I have mentioned several de-constructivist, decolonial theoretical approaches in the study of culture, which seek to de-stabilise and re-think established ascriptions and borders. Also in today's fields of practice, decolonization appears not yet to be completely fulfilled. In this case, I have summarized as decolonization any fight for liberation from any unequal power structures, which need not necessarily be grounded in the colonial era. However, in general, unequal power structures on a global scale cannot be separated from their colonial legacies due to their entanglement with neoliberal capitalistic structures, which could only expand as such through colonialism (Dussel, 1998).

To achieve decolonization, I have also mentioned several theoretical approaches such as organizing networks (Mbembe, 2016, p. 37) or taking into account decolonial feminist-queer southern epistemologies and new subjectivities (Gutiérrez Rodriguez, 2016). In my chapter here, William Jamal Richardson's call for action, and for intervening in "physical spaces" (2018, p. 232) rather than only in debates, comes into focus. How should we decolonize the global arts in practise? While discussing this question, I also reflect upon my own positionality, as well as on what Eve Tuck and K. Wayne Yang call the risk of using the term decolonization as a mere metaphor (Tuck \& Yang, 2012).

How can I write about issues of racism, inequality and decolonization as a White, heterosexual, privileged person from the "Global North"? Is this only appropriation, talking "about" and not "with" and/or the intention to white-wash myself from not really doing anything against inequalities and the collective guilt of colonialism? After all, knowledge production is always influenced by political interests (Richardson, 2018).

What does it mean when the tools of a racist patriarchy are used to examine the fruits of that same patriarchy? It means that only the most narrow perimeters of change are possible and allowable. ... For the master's tool will never dismantle the master's house. (Lorde, 1984, pp. 110-114) 
Audre Lorde criticizes how members of different minorities are merely used as tokens and reveals how White feminists are deeply racist. ${ }^{234}$ She also suggests how to work against these mechanisms, by urging everyone to "reach down into that deep place of knowledge inside herself and touch that terror and loathing of any difference that lives there. See whose face it wears" (Lorde, 1984, p. 114). Lorde appears to call not only to a process of honest self-reflection, but she also incorporates another notion of diversity and otherness, one that could be called a combination of intersectional with cross-cultural otherness. For her, differences should be acknowledged, as by shedding difference, no real community can develop. "Difference must be not merely tolerated, but seen as a fund of necessary polarities between which our creativity can spark like a dialectic” (Lorde, 1984, p. 110). In most of the literature which is discussed in my two chapters in this book, diversity is framed positively and connected to inclusionary narratives, while otherness is rather related to processes of exclusion. Lorde, however, offers a perspective that turns these approaches around. It is exactly the intersectional difference that should be made productive for fostering inclusion, decolonizing the racist patriarchy, and recognizing "difference as a crucial strength" (Lorde, 1984, p. 111). Likewise, real cooperation can form that might meet up with the emancipatory quest that cross-cultural otherness seeks.

In other research, Rosalba Icaza and Rolando Vázquez have inquired into how the combination of intersectional with decolonial frameworks can offer an application of a perspective similar to Lorde’s at the University of Amsterdam (Icaza \& Vázquez, 2018). They show how positionality, relationality and transitionality can support decolonizing in the university. "Practices of positionality ..., even while teaching the canon, reveal the geopolitical location of knowledge. ... Relationality ... includes a transformation of the relationships established in the classroom and across the university" (p. 119-120), by rendering valuable differences. Last but not least, "the question of transition points towards the need for the university to actively address its own societal and ecological implications by enabling the students to bridge the epistemic border between the classroom and society" (p. 120). Thus, we see three levels of possible action for decolonizing knowledge. Always reflect upon the position of knowledge, come to view differences as strength, and not only theorize but also act. Let us see later whether this approach could help decolonize the global arts-which can be taken as forms of knowledge production (Hall, 1981).

Tuck and Yang also call for action rather than only speaking, writing and reflecting about inequalities. When decolonization is misused as no more than a metaphor, it is in danger of serving only the settlers, colonialists (and their ancestors today) as "moves to innocence" (Tuck \& Yang, 2012, p. 3). Instead of using decolonization as a metaphor for any fight of social justice, for these scholars it should mean above all

234 bell hooks is another renowned scholar who addresses similar issues (hooks, 1995). 
repatriating the land from the colonizers to the colonized. In this case, those involved are the settlers to the First Nation People in the USA.

Decolonisation in the settler colonial context must involve the repatriation of land simultaneous to the recognition of how land and relations to land have always already been differently understood and enacted; that is, all of the land, and not just symbolically. This is precisely why decolonisation is necessarily unsettling, especially across lines of solidarity. (Tuck \& Yang, 2012, p. 7)

Even though I would not agree to use the term exclusively with regard to the US American context, what is important in Tuck's and Yang's approach is not only their unveiling of colonial legacies and various strategies to innocence, but for them, the fact that "decolonization is not an 'and'. It is an elsewhere” (p. 36). "Opportunities for solidarity lie in what is incommensurable rather than what is common” (p. 28). Thus, first, we need a diversity of decolonization practices. Secondly, as Lorde has described it, solidary cooperation arises in the bridges which are forged between people and communities, not in the commonalities. As I have discussed in my other chapter, Bruno Latour writes to make traceable all dynamic associations (Latour, 2010). This again relates to the transcultural approach of this volume, which oscillates between the negotiations and standardizations of differences and their transcultural practices, which in turn go beyond these (b-)ordering differences.

Several authors also present suggestions of how to decolonize the arts through implementing anti-racist (Bayer \& Terkessidis, 2017), decolonial (Caceres et al., 2017) or transcultural (Bhagwati, 2018; Lutz, 2018; von Osten, 2012) practices of curating. Besides the intersectional and cross-cultural strategies I have discussed for the avoidance of exclusion, fostering of representation and participation of underrepresented people and the increased visibility of minority perspectives within the arts sector, enabling reflection on hegemonic narratives and social inequalities, these curatorial approaches focus again on different aspects of joint cooperation (Sennett, 2012; Richter, 2012), polyphony (Bempeza et al., 2019), collectives (von Bismarck, 2012), social cohesion and conviviality (Heil, 2020; Espahangizi in this volume).

These partially activist debates and practical approaches emphasize both modes of solidarity and complicity as well as notions of conflict, complication and disruption (Dobusch et al., 2020). This means that any decolonial cooperation on a day-today level will inevitably involve conflict and disruption in order to foster new ways of doing things. "The moment of innovation is constituted here as conflictual permeation that initiates processes of hybridisation” (Büscher-Ulbrich et al., 2013, p. 17). This is what is meant by a transcultural way of inclusion, that involves critique and conflict as a major driving force.

A postcolonially oriented research agenda such as the one I propose seeks to dismantle all these different power-laden processes, by including many views through co-operation on an equal footing. This means that the terms and concepts with which we all operate in practice as well as in academia also need to be decolonized. I would 
instead suggest that we consider, research, teach and curate diversity as transcultural diversity. Lorenzo Ornaghi would probably speak of "glocal diversity", a "contamination" that exercises a genuinely "glocal power" beyond domestic and international politics (Ornaghi, 2017, p. 8). By transcultural diversity, I mean to underline that diversity cannot be fixed and defined. Instead, it is constructed and reconstructed or deconstructed every time by every curator, artist, cultural administrator or manager, student, audience, researcher, etc. Just as Ernesto Laclau and Chantal Mouffe have pled against apriorism (Laclau \& Mouffe, 2012), in every situation it is possible to construct a new way of thinking and acting.

The potential of the proposed transcultural perspective on global art that takes into account not only the global (and globalising) conditions of production but also specific localities is that it allows scholars to grasp cross-cultural connections, interactions as well as marginalised forms of knowledge and agency that are otherwise often overlooked or underestimated in their critical force. (Buurman et al., 2018, p. 18)

As the Cultural capabilities model-which is based on the capabilities approach of Martha Nussbaum and Amartya Sen-aims at fostering conditions of cultural opportunity in order to co-create versions of culture, in order to extend cultural democracy, this would mean including both top-down and bottom-up approaches as well as both global and local approaches. "It is only when 'substantive freedom' is realized in relation to culture-real, concrete freedoms to choose what culture to make, as well as what culture to appreciate-that people are genuinely empowered in their cultural lives” (Wilson et al., 2017, p. 5; Nussbaum, 2011; Sen, 2001).

By developing new approaches together with different partners, the study of culture can give valuable stimuli to discover new terms, concepts, cooperation forms, funding schemes, etc. for glocal spaces, without the claim of having either global or national effect. Nevertheless, it allows for more pluralistic voices and views to be taken into account, as J.P. Singh has suggested, and for the established thinking of a hierarchy of needs to transform into thinking about networks of possibilities (Singh, 2019).

Such transcultural insights into curating diversity and otherness also entails that we cannot answer the question of how to curate diversity and otherness, as the answer will always be bound to a radical diversity of possibilities and is never able to aim at universalism. However, we can instead learn from practice by looking at examples of how to decolonize the arts in general or the global performance arts more specifically. For this approach, we have learnt that it is important to expose unequal power structures as well as to overcome dichotomies in our own individual and collective thinking. However, this needs to go a lot farther still. In the arts, dichotomies in thinking are not only present regarding (e.g.) the border drawn between "Western" and "non-Western" art and artists. Dichotomies also target the way that things are expected to be done. For instance, in the German cultural sector, results are mainly measured through financial means, success, and evaluation. Artists and audiences 
are separated and performances are organized and scheduled. However, in different contexts, not even the division between different artistic genres necessarily exists. (Jansen, personal communication, October 17, 2018) What is needed then to overcome these and other dichotomies, is to "always stay in contact. First of all to ask the person, from which position are you speaking to me? What is my position? This negotiation has to start in the first second [of meeting each other]"235 (Jansen, personal communication, October 17, 2018). Thus, cooperation on eye-level, decolonial curating and practices of transcultural diversity involve questioning all presuppositions and acknowledging other knowledge systems, concepts of art, practices of cultural expressions. But this must not necessarily lead to or hinder conflict. On the contrary, it is really a process of negotiations, of "situational practices, no determined categories"236 (Jansen, personal communication, October 17, 2018).

Some Goethe Institutes in African countries now follow an approach of putting the power into the hands of local artists and not only collaborating with them, but letting them decide what and how to curate, and how to organize the cooperation by deciding on the use of these Goethe funds. An important factor for successful cooperation is transparency about decisions, finances, concepts, etc. Everyone involved should have the opportunity to partake in every process. But the desire to "always make everything right [leads to] forgetting to just talk with the people. ... One is permanently in discourse, but actually never really in contact"237 (Jansen, personal communication, October 17, 2018). So the question remains, “[W]here can we meet?"238 (Jansen, personal communication, October 17, 2018). This is again not to be answered generally, but needs to be negotiated every time anew. Curators understood in the etymological sense of the term as "carers" should "stop working with signs and stop representing, but should work rather with presence than with absence"239 (Jansen, personal communication, October 17, 2018). Only in such situational practices of relations, can curating diversity and otherness as neo-colonial be overcome and can it transform practices of representation. "It is not about the structure, it is about the

235 "immer in Kontakt bleiben. Erst einmal die Person fragen, von welcher Position aus sprichst du mit mir? Was ist meine Position? Die Verhandlung muss in der ersten Sekunde anfangen” (Jansen, personal communication, October 17, 2018).

236 "situative Praktiken, keine festgelegten Kategorien" (Jansen, personal communication, October $17,2018)$.

237 "immer alles richtig machen zu wollen - und dabei zu vergessen mit den Leuten eigentlich selbst zu reden. ... man ist die ganze Zeit, permanent im Diskurs und ist eigentlich nie in Kontakt" (Jansen, personal communication, October 17, 2018).

238 “Wo können wir uns treffen?” (Jansen, personal communication, October 17, 2018).

239 "aufhören, mit Zeichen zu arbeiten und zu repräsentieren, sondern mit der Anwesenheit, nicht in der Abwesenheit" (Jansen, personal communication, October 17, 2018). 
relation. It is about the agency"240 (Jansen, personal communication, October 17, 2018). Such an approach could be "the product of communication beyond space and time, beyond territorial boundaries. It questions out-dated ideas of culture, identity and community" (Burkhalter, 2012, p. 30), and can lead to a transcultural understanding of diversity and otherness as a way of decolonizing curating in global performance art.

\section{References}

Abbing, H. (2019). The Changing Social Economy of Art: Are the Arts Becoming Less Exclusive? (1st ed. 2019). Palgrave Macmillan. https://doi.org/10.1007/978-3-030-21668-9

Ahmed, S. (2012). On Being Included: Racism and Diversity in Institutional Life. e-Duke books scholarly collection. Duke University Press. http://lib.myilibrary.com?id=366424

Alfred Toepfer Stiftung (n.d.). Kairos-Preis 2011: Shermin Langhoff. Retrieved November 24, 2019, from https://www.toepfer-stiftung.de/kairos-preis-2/kairos-preis-2011/

Alisch, S., Binas-Preisendörfer, S., \& Jauk, W. (Eds.). (2018). Darüber hinaus ... Populäre Musik und Überschreitung(en): 2. laspm D-A-CH Konferenz/Graz 2016. BIS-Verlag der Carl von Ossietzky Universität.

Allerstorfer, J., \& Leisch-Kiesl, M. (Eds.). (2017). Linzer Beiträge zur Kunstwissenschaft und Philosophie: Band 8. "Global Art History“: Transkulturelle Verortungen von Kunst und Kunstwissenschaft. transcript.

Amīn, K. (2014). Postcolonial Modernity: Theatre in Morocco and the Interweaving Loop. In E. Fischer-Lichte, T. Jost, \& S. I. Jain (Eds.), Routledge Advances in Theatre and Performance Studies: Vol. 33. The politics of interweaving performance cultures: Beyond postcolonialism (pp. 25-41). Routledge.

Amīn, K., \& Laamiri, M. (2010). Performing cultural diversity: Critiquing postcolonialism (1st ed). Series: Conderences and colloquia. Université Abdelmalek Essaâdi, Faculty of Letters and Humanities, Research Group of Performance Studies.

Angermüller, J., \& Bellina, L. (2012). Poststrukturalismus und Postkolonialismus: Jacques Derridas "Grammatologie" sowie Gilles Deleuzes und Félix Guattaris "Tausend Plateaus". In J. Reuter \& A. Karentzos (Eds.), Schlüsselwerke der Postcolonial Studies (Vol. 20, pp. 27-37). VS Verlag für Sozialwissenschaften. https://doi.org/10.1007/978-3-531-93453-2_2

Apter, E. S. (2013). Against world literature: On the politics of untranslatability. Verso.

Archer, M. S. (2005). Structure, Culture and Agency. In M. D. Jacobs \& N. Weiss Hanrahan (Eds.), The Blackwell Companion to the Sociology of Culture (pp. 17-34). Blackwell Publ.

Austin, J. L. (2014). Zur Theorie der Sprechakte: $=$ (How to do things with words) ([Nachdr.], bibliogr. erg. Ausg). Reclams Universal-Bibliothek: Nr. 9396. Reclam.

Bachmann-Medick, D. (Ed.). (2016). The trans/national study of culture: A translational perspective. De Gruyter.

Bayer, N., \& Terkessidis, M. (2017). Über das Reparieren hinaus: Eine antirassistische Praxeologie des Kuratierens. In N. Bayer, B. Kazeem-Kamiński, \& N. Sternfeld (Eds.), Edition Angewandte. Kuratieren als antirassistische Praxis (pp. 53-70). De Gruyter.

240 "Es geht nicht um die Struktur. Es geht um die Beziehung. Um die Handlungsmacht” (Jansen, personal communication, October 17, 2018). 
Becker, H. S. (2008). Art worlds. University of California Press.

Behnke, C., Kastelan, C., Knoll, V., \& Wuggenig, U. (Eds.). (2015). Art in the periphery of the center. Sternberg Press.

Below, I., \& Bismarck, B. von (Eds.). (2005). Schriftenreihe des Ulmer Vereins, Verband für Kunstund Kulturwissenschaften e.V: N.F., Bd. 1. Globalisierung, Hierarchisierung: Kulturelle Dominanzen in Kunst und Kunstgeschichte. Jonas-Verl.

Bempeza, S., Brunner, C., Hausladen, K., Kleesattel, I., \& Sonderegger, R. (Eds.). (2019). Polyphone Ästhetik: Eine kritische Situierung. transversal texts.

Benzer, S. (Ed.). (2016). Kultur für alle: Gespräche über Verteilungsgerechtigkeit und Demokratie in Kunst und Kultur heute ([1. Auflage]). Folio Verlag.

Beyer, T., \& Burkhalter, T. (Eds.). (2012). Out of the absurdity of life: Globale Musik (1. Aufl.). Traversion.

Beyer, T., Burkhalter, T., \& Liechti, H. (Eds.). (2015). Seismographic sounds: Visions of a new world (1. edition). Norient.

Bhagwati, A. (2018). Of Maps, Nodes and Trajectories: Changing Topologies in Transcultural Curating. In S. Dornhof, N. Buurman, B. Hopfener, \& B. Lutz (Eds.), Image: Vol. 89. Situating Global Art: Topologies - Temporalities - Trajectories (pp. 191-211). transcript.

Bhambra, G. K., Gebrial, D., \& Nişancıoğlu, K. (Eds.). (2018). Decolonising the university. Pluto Press.

Bharucha, R. (2001). The politics of cultural practice: Thinking through theatre in an age of globalization. Oxford Univ. Press.

Bial, H. (Ed.). (2004). The performance studies reader. Routledge. http://catdir.loc.gov/catdir/ enhancements/fy0650/2003005708-d.html

Binas-Preisendörfer, S. (2008). Musik - eine Weltsprache? Befunde und Vorschläge zur Dekonstruktion eines Mythos. In E. Schwind \& O. Senn (Eds.), Musik - Wahrnehmung - Sprache: Eine Publikation der Musikhochschule Luzern (pp. 163-173). Chronos. https://uol.de/ fileadmin/user_upload/musik-medien/Medien/Susanne-Binas-Preisendoerfer_Musik-eineWeltsprache_2008.pdf

Bishop, S. (2018, May 23). With calls for more diversity in music festivals, is Forecastle doing enough? Leo Weekly Online. https://www.leoweekly.com/2018/05/forecastle-enough

Bismarck, B. v. (2012). The Exhibition as Collective. In B. v. Bismarck, J. Schafaff, \& T. Weski (Eds.), Cultures of the curatorial: [... Based on the Conference "Cultures of the Curatorial" at the Hochschule für Grafik und Buchkunst - Academy of Visual Arts Leipzig, January 22 - 24, 2010] (pp. 289-302). Sternberg Pr.

Bourdieu, P. (1978). Entwurf einer Theorie der Praxis auf der ethnologischen Grundlage der kabylischen Gesellschaft (1. Aufl.). Suhrkamp.

Bourdieu, P. (1993). The field of cultural production: Essays on art and literature. European perspectives. Columbia University Press.

Brockington, G. (2009). Introduction: Internationalism and the Arts. In G. Brockington (Ed.), Cultural interactions: vol. 4. Internationalism and the arts in Britain and Europe at the fin de siècle (pp. 1-24). P. Lang.

Buchholz, L., \& Wuggenig, U. (2005). Cultural Globalization Between Myth and Reality: The Case of the Contemporary Visual Arts. ART-E-FACT Strategies of Resistance (4). http://artefact.mi2. $\mathrm{hr} /$ _a04/lang_en/theory_buchholz_en.htm

Buchholz, L., \& Wuggenig, U. (2012). Kunst und Globalisierung. In H. Munder \& U. Wuggenig (Eds.), Das Kunstfeld: Eine Studie über Akteure und Institutionen der zeitgenössischen Kunst am Beispiel von Zürich, Wien, Hamburg und Paris (pp. 163-188). JRP/Ringier.

Buden, B. (2012). Towards the Heterosphere: Curator as Translator. In M. Lind (Ed.), Performing the curatorial: Within and beyond art (pp. 23-46). Sternberg Press. 
Burkhalter, T. (2012). Weltmusik 2.0: Musikalische Positionen zwischen Spass- und Protestkultur. In T. Beyer \& T. Burkhalter (Eds.), Out of the absurdity of life: Globale Musik (1st ed., pp. 28-47). Traversion. https://norient-beta.com/academic/weltmusik2-0/

Büscher-Ulbrich, D., Kadenbach, S., \& Kindermann, M. (2013). Einleitung: »The More Things Change«. In D. Büscher-Ulbrich, S. Kadenbach, \& M. Kindermann (Eds.), Kultur- und Medientheorie. Innovation - Konvention: Transdisziplinäre Beiträge zu einem kulturellen Spannungsfeld (pp. 7-20). transcript.

Buț, G. (2017, August 31). Internationalisation as the (Invisible) Curated Object. European Sociological Association. 13th Conference of the European Sociological Association. (Un) Making Europe: Capitalism, Solidarities, Subjectivities, Athens.

Butler, J. (2013). Excitable Speech: A Politics of the Performative. Taylor and Francis.

Buurman, N., Dornhof, S., Hopfener, B., \& Lutz, B. (2018). Situating Global Art: An Introduction. In S. Dornhof, N. Buurman, B. Hopfener, \& B. Lutz (Eds.), Image: Vol. 89. Situating Global Art: Topologies - Temporalities - Trajectories (pp. 11-32). transcript.

Caceres, I., Mesquita, S., \& Utikal, S. (2017). Anti*Colonial Fantasies/ Decolonial Strategies: A Conversation. In N. Bayer, B. Kazeem-Kamiński, \& N. Sternfeld (Eds.), Edition Angewandte. Kuratieren als antirassistische Praxis (pp. 201-211). De Gruyter.

Cañas, T. (2017). Diversity is a white word: The superficial scramble for cultural diversity is not addressing the deep causes of exclusion and the power imbalance in the arts. https://www. artshub.com.au/education/news-article/opinions-and-analysis/professional-development/ tania-canas/diversity-is-a-white-word-252910

Cassin, B., \& Apter, E. S. (Eds.). (2014). Translation / transnation. Dictionary of untranslatables: A philosophical lexicon (S. Rendall, Trans.). Princeton University Press. https://www.jstor.org/ stable/j.ctt5hhntn https://doi.org/10.2307/j.ctt5hhntn

Charle, C., Lüsebrink, H. J., \& Mix, Y. G. (Eds.). (2017). Deutschland und Frankreich im wissenschaftlichen Dialog / Le dialogue scientifique franco-allemand: Volume 6. Transkulturalität nationaler Räume in Europa (18. bis 19. Jahrhundert): Übersetzungen, Kulturtransfer und Vermittlungsinstanzen $=$ La transculturalité des espaces nationaux en Europe (XVIIIe-XIXe siècles); traductions, transferts culturels et instances de médiations (1. Auflage). V\&R Unipress. https://www.vr-elibrary.de/isbn/9783847104797 https://doi.org/10.14220/9783737004794

Cuyler, A. (2019). The Role of Foundations in Achieving Creative Justice. GIA Reader, 30 (1), Article 6. https://www.giarts.org/role-foundations-achieving-creative-justice

Dätsch, C. (Ed.). (2018). Edition Kulturwissenschaft: Band 103. Kulturelle Übersetzer: Kunst und Kulturmanagement im transkulturellen Kontext. https://doi.org/10.14361/9783839434994

Davida, D. (Ed.). (2011). Fields in motion: Ethnography in the worlds of dance. Wilfrid Laurier University Press. http://lib.myilibrary.com/detail.asp?id=380988

Davida, D., Pronovost, M., Hudon, V., \& Gabriels, J. (Eds.). (2019). Curating Live Arts: Global Perspectives on Theory and Practice. Berghahn Books Incorporated.

Di Blasi, J. (2019). Das Humboldt Lab: Museumsexperimente zwischen postkolonialer Revision und szenografischer Wende. transcript. https://doi.org/10.14361/9783839449202

Do Mar Castro Varela, María, \& Haghighat, L. (Eds.). (2020). Double Bind postkolonial: Kritische Perspektiven auf Kunst und Kulturelle Bildung. Transcipt Verlag.

Dobusch, L., Kreissl, K., \& Wacker, E. (Eds.). (2020). Diversitätsforschung: Von der Rekonstruktion zur Disruption [Special issue]. ZDfm - Zeitschrift für Diversitätsforschung und -Management, 5(1). Leverkusen-Opladen. Barbara Budrich.

Dorn, C. (2004). The Deterritorialization of Art. The Journal of Arts Management, Law, and Society, 34(2), 141-150. https://doi.org/10.3200/JAML.34.2.141-150

Dornhof, S., Buurman, N., Hopfener, B., \& Lutz, B. (Eds.). (2018). Image: v.89. Situating Global Art: Topologies - Temporalities - Trajectories (1st ed.). transcript. 
Douglas, G., Sichel, A., Liadi, A. M., Noël, K., Danster, R., Cuvilas, A., \& Linyekula, F. (2006). Under Fire: Defining a contemporary African dance aesthetic - can it be done? Critical Arts, 20(2), 102-115. https://doi.org/10.1080/02560040608540458

Dovey, L. (2015). Curating Africa in the Age of Film Festivals. Framing Film Festivals. Palgrave Macmillan.

Durrant, S. (Ed.). (2007). Thamyris, intersecting: Vol. 17. Essays in migratory aesthetics: Cultural practices between migration and art-making. Rodopi.

Durrer, V., \& Henze, R. (Eds.). (2020). Managing Culture: Reflecting on Exchange in Global Times. Sociology of the Arts. Palgrave Macmillan. https://doi.org/10.1007/978-3-030-24646-4

Dussel, E. (1998). Beyond eurocentrism: The world-system and the limits of modernity. In F. Jameson \& M. Miyoshi (Eds.), The cultures of globalization (pp. 3-31). Duke Univ. Press.

Enwezor, 0. (2002). Demokratie als unvollendeter Prozess: Documenta 11, Plattform 1; [dieser Band enthält alle Beiträge der Documenta 11 - Plattform 1 "Demokratie als Unvollendeter Prozess“, einer Reihe von Konferenzen und Vorträgen in Wien, Akademie der Bildenden Künste, 15. März 20. April 2001, und in Berlin, Haus der Kulturen der Welt, 9. - 30. Oktober 2001.] Hatje Cantz.

Eremjan, I. (2016). Transkulturelle Kunstvermittlung: Zum Bildungsgehalt ästhetisch-künstlerischer Praxen. Pädagogik. transcript.

Ette, O. (2017). WeltFraktale: Wege durch die Literaturen der Welt. J.B. Metzler.

Fischer-Lichte, E. (2004). Ästhetik des Performativen (Orig.-Ausg., 1. Aufl.). Edition suhrkamp: Vol. 2373. Suhrkamp.

Fischer-Lichte, E. (2014). Introduction: Interweaving performance cultures; rethinking "intercultural theatre"; toward an experience and theory of performance beyond postcolonialism. In E. Fischer-Lichte, T. Jost, \& S. I. Jain (Eds.), Routledge Advances in Theatre and Performance Studies: Vol. 33. The politics of interweaving performance cultures: Beyond postcolonialism (pp. 1-21). Routledge.

Fischer-Lichte, E., \& Roselt, J. (2001). Attraktion des Augenblicks: Aufführung, Performance, performativ und Performativität als theaterwissenschaftliche Begriffe. Theorien des Performativen, 237-253.

Fischer-Lichte, E., Jost, T., \& Jain, S. I. (Eds.). (2014). Routledge Advances in Theatre and Performance Studies: Vol. 33. The politics of interweaving performance cultures: Beyond postcolonialism. Routledge.

Foroutan, N. (2012). Neue Deutsche, Postmigranten und Bindungs-Identitäten: Wer gehört zum neuen Deutschland? In J. Manemann \& W. Schreer (Eds.), Quellen und Studien zur Geschichte und Kunst im Bistum Hildesheim: Vol. 6. Religion und Migration heute: Perspektiven Positionen - Projekte; [Norbert Trelle, Bischof von Hildesheim, zum 70. Geburtstag] (1st ed., pp. 111-121). Schnell + Steiner.

Foroutan, N. (2016). Postmigrantische Gesellschaften. In H. U. Brinkmann \& M. Sauer (Eds.), Einwanderungsgesellschaft Deutschland: Entwicklung und Stand der Integration (pp. 227-254). Springer VS.

Gaupp, L. (2016). Die exotisierte Stadt: Kulturpolitik und Musikvermittlung im postmigrantischen Prozess. Studies in Music: Vol. 1. Olms. https://hildok.bsz-bw.de/frontdoor/index/index/ docld $/ 547$

Gaupp, L. (2018). Symbolische Räume kultureller Diversität: Verhandlungen, Grenzen und Überschreitungen in den performativen Künsten. In M. Nies (Ed.), Schriften zur Kultur- und Mediensemiotik Online: Vol. 4. Raumsemiotik: Räume - Grenzen - Identitäten (pp. 241-259). Virtuelles Zentrum für kultursemiotische Forschung.

Gaupp, L. (2020). The 'West' versus 'the Rest'? Festival Curators as Gatekeepers for Sociocultural Diversity. In V. Durrer \& R. Henze (Eds.), Managing Culture: Reflecting on Exchange in Global Times. Sociology of the Arts. Palgrave Macmillan. 
Gaupp, L., Abramjan, A., Akinay, F. M., Hilgert, K., Mulder, A. C., Schmidt, R., Schnitzler, V., Thurich, O., Tiemon, L., \& Wurl, S. (2020). Curatorial practices of the "Global": Toward a Decolonial Turn in the Museum in Berlin and Hamburg? Journal of Cultural Management and Cultural Policy, Special Issue: Museum - Politics - Management. 2020(2), 107-138.

Gaupp, L., Barber-Kersovan, A., \& Kirchberg, V. (Eds.). (2021). Arts and Power: Policies in and by the Arts. Serie Kunst und Gesellschaft. Springer VS.

Goodman, L., \& DeGay, J. (Eds.). (2000). Performance Studies. The Routledge reader in politics and performance.

Guilbault, J. (1997). Interpreting World Music: A Challenge in Theory and Practice. Popular Music, 16(1), 31-44.

Gutiérrez Rodriguez, E. (2016). Decolonizing Postcolonial Rhetoric. In E. Gutiérrez Rodriguez, M. Boatcă, \& S. Costa (Eds.), Global connections. Decolonizing European sociology: Transdisciplinary approaches (pp. 49-67). Routledge Taylor \& Francis Group.

Haakh, N. (2015). Muslimisierte Körper auf der Bühne: Die Islamdebatte im postmigrantischen Theater. transcript.

Haberkorn, S. (2010). Neues Publikum für Kunst und Kultur gewinnen? Eine empirische Untersuchung zum Audience Development am Beispiel des Festivals der Kulturen MELEZ. VDM Verlag Dr. Müller.

Hall, S. (1981). The Whites of their Eyes: Racist Ideologies and the Media. In G. Bridges \& R. Brunt (Eds.), Contributions to the Communist University of London. Silver Linings: Some strategies for the eighties (pp. 28-52). Lawrence \& Wishart.

Hall, S. (1994). The West and the Rest: Discourse and Power. In S. Hall \& B. Gieben (Eds.), The Formations of Modernity: (Introduction to Sociology) (pp. 275-331). Polity Press.

Hauthal, J., \& Toivanen, A. L. (Eds.). (2021). European Peripheries in the Postcolonial Literary Imagination [Special issue]. Journal of Postcolonial Writing, 57. Routledge Taylor \& Francis Group.

Heeg, G. (2017). Das transkulturelle Theater. Recherchen: Vol. 130. Theater der Zeit.

Heeg, G., \& Hillmann, L. (Eds.). (2017). Recherchen: Vol. 134. Willkommen anderswo - sich spielend begegnen. Theater der Zeit.

Heil, T. (2020). Comparing Conviviality: Living with Difference in Casamance and Catalonia. Palgrave Macmillan.

Henze, R. (2017). Why we have to overcome paternalism in times of populism. In M. Dragićević Šešić, L. Rogač Mijatović, \& N. Mihaljinac (Eds.), Cultural diplomacy: Arts, festivals and geopolitics (pp. 73-89). Culture Desk Serbia Creative Europe Desk Serbia; Faculty of Dramatic Arts in Belgrade Institute for Theatre Film Radio and Television.

Hitzke, D. (2019). Nach der Einsprachigkeit: Slavisch-deutsche Texte transkulturell. Postcolonial Perspectives on Eastern Europe: Vol. 6. Peter Lang GmbH, Internationaler Verlag der Wissenschaften.

hooks, b. (1995). Ain't I a woman: Black women and feminism (5. print). Pluto Press.

Horst, M. t., \& Schwartz, G. (Eds.). (2012). Changing perspectives: Dealing with globalisation in the presentation and collection of contemporary art. KIT.

Horz, C. (2014). Medien - Migration - Partizipation: Eine Studie am Beispiel iranischer Fernsehproduktion im Offenen Kanal. transcript.

Icaza, R., \& Vázquez, R. (2018). Diversity or Decolonisation? Researching Diversity at the University of Amsterdam. In G. K. Bhambra, D. Gebrial, \& K. Nişancıoğlu (Eds.), Decolonising the university (pp. 108-128). Pluto Press.

Jungwirth, I. (2019). Introduction: Gender and Diversity Studies: European Perspectives. In I. Jungwirth \& C. Bauschke-Urban (Eds.), Gender and Diversity Studies: European Perspectives (pp. 9-30). Verlag Barbara Budrich. 
Kagan, S. (2011). Art and Sustainability: Connecting Patterns for a Culture of Complexity. transcript. http://www.transcript-verlag.de/ts1803/ts1803.php

Kampnagel (2019). Migrantpolitan: X-Mas Party. Retrieved December 18, 2019, from https://www. kampnagel.de/en/program/migrantpolitan-x-mas-party

Karentzos, A. (2012). Postkoloniale Kunstgeschichte. Revisionen von Musealisierungen, Kanonisierungen, Repräsentationen. In J. Reuter \& A. Karentzos (Eds.), Schlüsselwerke der Postcolonial Studies (Vol. 2010, pp. 249-266). VS Verlag für Sozialwissenschaften. https://doi. org/10.1007/978-3-531-93453-2_19

Kaup-Hasler, V. (2012). In NXTSTP (Ed.), NXT.STP: Documentation 2007-2012. http://www.nxtstp.eu/ files/NXTSTP_5_years.pdf

Keuchel, S., \& Kelb, V. (Eds.). (2015). Perspektivwechsel Kulturelle Bildung: v.1. Diversität in der Kulturellen Bildung. transcript.

Khatibi, A. (1985). Double Criticism: The Decolonization of Arab Sociology. In H. I. Barakat (Ed.), Contemporary North Africa: Issues of development and integration (pp. 9-19). Croom Helm.

Kim, J. A., \& Riva, N. (Eds.). (2014). Entgrenzte Welt? Musik und Kulturtransfer (1. Aufl.). Ries \& Erler.

Klein, G. (2013). Übersetzen und Rahmen: Aufführungen in globalisierten Pop(ulär)kulturen. In D. Helms \& T. Phleps (Eds.), Ware Inszenierungen: Performance, Vermarktung und Authentizität in der populären Musik (pp. 211-222). transcript.

Köhl, C. (2001). Strategien der interkulturellen Kulturarbeit. IKO - Verl. für Interkulturelle Kommunikation.

Kolsteeg, J. (2019). Inclusiviteit is de praktijk: Grand Theatre Groningen. Boekman Extra - Trends in Kunst En Cultuur (19), 1-10. https://www.boekman.nl/wp-content/uploads/2019/12/ BmXtra_19_DEF-1.pdf

Kraus, M., \& Noack, K. (Eds.). (2015). Edition Museum: v.16. Quo vadis, Völkerkundemuseum? Aktuelle Debatten zu ethnologischen Sammlungen in Museen und Universitäten. transcript.

Krüger, S. (2013). Undoing anthenticity as a discursive construct: A critical pedagogy of ethnomusicology and "world music". In B. Alge \& O. Krämer (Eds.), Berliner Schriften: Band 116. Beyond borders: Welt - Musik - Pädagogik: Musikpädagogik und Ethnomusikologie im Diskurs (pp. 93-113). Wißner.

Laclau, E., \& Mouffe, C. (2012). Hegemonie und radikale Demokratie: Zur Dekonstruktion des Marxismus (Dt. Erstausg., 4., durchges. Aufl.). Passagen Philosophie. Passagen Verlag.

Latour, B. (2010). Eine neue Soziologie für eine neue Gesellschaft: Einführung in die AkteurNetzwerk-Theorie (1. Aufl.). Suhrkamp-Taschenbuch Wissenschaft: Vol. 1967. Suhrkamp.

Leeb, S. (2015). Entangled: But How? In C. Behnke, C. Kastelan, V. Knoll, \& U. Wuggenig (Eds.), Art in the periphery of the center (pp. 210-219). Sternberg Press.

Lena, J. C. (2019). Entitled: Discriminating tastes and the expansion of the arts. Princeton University Press.

Lettau, M., \& Knoblich, C. (2017). Foreign cultural policy in processes of transformation: Perceptions of German-Tunisian cultural exchange. ENCATC Journal of Cultural Management and Policy, 7(1). https://www.encatc.org/media/3725-7_encact-vol-7_meike-lettau-caroline-knoblich.pdf

Lind, M. (2012). Performing the Curatorial: An Introduction. In M. Lind (Ed.), Performing the curatorial: Within and beyond art (pp. 9-22). Sternberg Press.

Lorde, A. (1984). Sister outsider: Essays and speeches. The Crossing press feminist series. Crossing Press. https://collectiveliberation.org/wp-content/uploads/2013/01/Lorde_The_Masters_ Tools.pdf

Lutz-Sterzenbach, B., Schnurr, A., \& Wagner, E. (Eds.). (2013). Pädagogik. Bildwelten remixed: Transkultur, Globalität, Diversity in kunstpädagogischen Feldern. transcript.

Lutz, B. (2018). Curating as Transcultural Practice: Documenta 12 and the "Migration of Form". In S. Dornhof, N. Buurman, B. Hopfener, \& B. Lutz (Eds.), Image: Vol. 89. Situating Global Art: Topologies - Temporalities - Trajectories (pp. 213-230), transcript. 
Macdonald, S. (Ed.). (1996). Theorizing museums: Representing identity and diversity in a changing world. Blackwell.

Mandel, B. (2014). Interkulturelles Audience Development: Zukunftsstrategien für öffentlich geförderte Kultureinrichtungen. Schriften zum Kultur- und Museumsmanagement. transcript.

Maxim Gorki Theatre Berlin (n.d.). Shermin Langhoff. Retrieved November 24, 2019, from https:// www.gorki.de/de/ensemble/shermin-langhoff

Mbembe, A. J. (2016). Decolonizing the university: New directions. Arts and Humanities in Higher Education, 15(1), 29-45. https://doi.org/10.1177/1474022215618513

Moore, M. (2017, January 22). Conway: Trump spokesman gave 'alternative facts'. New York Post. https://nypost.com/2017/01/22/conway-trump-spokesman-gave-alternative-facts-on-inauguration-crowd/

Mosquera, G. (1994). Some Problems in Transcultural Curating. In J. Fisher (Ed.), Global visions: Towards a new internationalism in the visual arts (1st ed., pp. 133-139). Kala Press in association with the Institute of International Visual Arts.

NORIENT (Ed.). (2020). Norient Space: The Now In Sound. https://www.startnext.com/en/norient

Nussbaum, M. C. (2011). Creating capabilities: The human development approach. Belknap Press of Harvard University Press. https://doi.org/10.4159/harvard.9780674061200

Ornaghi, L. (2017). Does Glocal Political Power Already Exist? Glocalism. Journal of Culture, Politics and Innovation (1), 1-11. https://glocalismjournal.org/does-glocal-political-power-alreadyexist/

Osborne, P. (2013). Global modernity and the contemporary: Two categories of the philosophy of historical time. In C. Lorenz \& B. Bevernage (Eds.), Schriftenreihe der FRIAS School of History: Band 007. Breaking up Time: Negotiating the Borders between Present, Past and Future (1st ed., pp. 69-84). Vandenhoeck \& Ruprecht.

Osten, M. von. (2012). Displaying the Absent: Exhibiting Transcultural Modernism. In B. v. Bismarck, J. Schafaff, \& T. Weski (Eds.), Cultures of the curatorial: [... Based on the Conference "Cultures of the Curatorial" at the Hochschule für Grafik und Buchkunst - Academy of Visual Arts Leipzig, January 22 - 24, 2010] (pp. 189-212). Sternberg Pr.

Peres da Silva, G. (2017). Weltmusik: Ein politisch umstrittener Begriff. In C. Leggewie \& E. Meyer (Eds.), Global Pop: Das Buch zur Weltmusik (1st ed., pp. 9-16). J.B. Metzler Verlag.

Peres da Silva, G., \& Hondros, K. (Eds.). (2019). Music and sound culture: volume 35. Music practices across borders: (e)valuating space, diversity and exchange (1. Auflage). transcript.

Pilić, I., \& Wiederhold, A. (2015). Kunstpraxis in der Migrationsgesellschaft: Transkulturelle Handlungsstrategien am Beispiel der Brunnenpassage Wien = Art practices in the migration society; transcultural strategies in action at Brunnenpassage in Vienna. Vol. 48. transcript; Brunnenpassage.

Pitchfork (n.d.). Are Music Festival Lineups Getting Worse? Retrieved June 18, 2018, from https:// pitchfork.com/features/festival-report/10059-are-music-festival-lineups-getting-worse/

Rajewsky, I. O. (2002). Intermedialität. UTB für Wissenschaft Medien- und Kommunikationswissenschaft: Vol. 2261. Francke.

Reckwitz, A. (2005). Kulturelle Differenzen aus praxeologischer Perspektive: Kulturelle Globalisierung jenseits von Modernisierungstheorie und Kulturessentialismus. In I. Srubar (Ed.), Kulturen vergleichen: Sozial- und kulturwissenschaftliche Grundlagen und Kontroversen (1st ed., pp. 92-111). VS Verl. für Sozialwiss.

Richardson, W. J. (2018). Understanding Eurocentrism as a Structural Problem of Undone Science. In G. K. Bhambra, D. Gebrial, \& K. Nişancıoğlu (Eds.), Decolonising the university (pp. 231-247). Pluto Press.

Richter, D. (2012). Artists and Curators as Authors: Competitors, Collaborators, or Teamworkers? In B. v. Bismarck, J. Schafaff, \& T. Weski (Eds.), Cultures of the curatorial: [... Based on the 
Conference "Cultures of the Curatorial" at the Hochschule für Grafik und Buchkunst - Academy of Visual Arts Leipzig, January 22 - 24, 2010] (pp. 229-248). Sternberg Pr.

Rosendahl Thomsen, M. (2008). Mapping World Literature: International Canonization and Transnational Literatures. Continuum Literary Studies. Bloomsbury Publishing.

Rother, L. (2017). Kunst durch Kredit: Die Berliner Museen und ihre Erwerbungen von der Dresdner Bank 1935. De Gruyter. https://doi.org/10.1515/9783110496093

Rugg, J., \& Sedgwick, M. (Eds.). (2012). Issues in curating contemporary art and performance. Intellect.

Sardinha, J., \& Campos, R. (Eds.). (2016). Transglobal sounds: Music, youth and migration. Bloomsbury Academic.

SAVVY Contemporary (Ed.). SAVVY Contemporary. The Laboratory of Form-Ideas: A CONCEPT reloaded. https://savvy-contemporary.com/site/assets/files/2811/savvy_concept_2017.pdf

Schatzki, T. R. (1996). Social practices: A Wittgensteinian approach to human activity and the social. Cambridge Univ. Press.

Schneider, W., \& Gad, D. (Eds.). (2014). Studien zur Kulturpolitik. Cultural Policy: Vol. 16. Good Governance for Cultural Policy: An African-European Research about Arts and Development (1st, New ed.). Peter Lang GmbH Internationaler Verlag der Wissenschaften. https://doi. org/10.3726/978-3-653-03932-0

Seliger, I. (2011). The aesthetics of transcultural desire: Borderline interventions in Miao Xiaochun's The last judgment in cyberspace and The last judgment in cyberspace - where will I go? In $\mathrm{H}$. Belting, J. Birken, A. Buddensieg, \& P. Weibel (Eds.), Global studies: Mapping contemporary art and culture (pp. 174-193). Hatje Cantz.

Sen, A. (2001). Development as freedom. Oxford University Press paperback. Univ. Press.

Sennett, R. (2003). Respect in a world of inequality (1. ed.). W. W. Norton.

Sennett, R. (2012). Together: The rituals, pleasures, and politics of cooperation. Yale University Press. http://lib.myilibrary.com/detail.asp?ID=340905

Sharifi, A. (2011). Theater für Alle? Partizipation von Postmigranten am Beispiel der Bühnen der Stadt Köln. Zugl.: Hildesheim, Univ., Diss., 2011. Studien zur Kulturpolitik: Vol. 13. Peter Lang $\mathrm{GmbH}$ Internationaler Verlag der Wissenschaften.

Shevtsova, M. (2009). Sociology of theatre and performance. Sociology, communication and performing media. QuiEdit.

Sievers, N., Dengel, S., Blumenreich, U., \& Hippe, W. (Eds.). (2018). Jahrbuch für Kulturpolitik: Vol. 16. Jahrbuch für Kulturpolitik 2017/18: Welt. Kultur. Politik. - Kulturpolitik in Zeiten der Globalisierung. transcript. https://doi.org/10.14361/9783839442524

Singh, J. P. (2019). Culture and International Development: Towards an Interdisciplinary Methodology [A study commissioned by the British Council]. https://www.britishcouncil.org/ sites/default/files/final_manuscript_cultureintldev.pdf

Small, C. (2010). Musicking: The meanings of performing and listening. Music/culture. Wesleyan Univ. Press.

Smith, T., Enwezor, O., \& Condee, N. (Eds.). (2009). Antinomies of art and culture: Modernity, postmodernity, contemporaneity. Duke University Press.

Stiftung Humboldt Forum im Berliner Schloss (n.d.). The Humboldt Forum im Berliner Schloss. Retrieved February 27, 2020, from https://www.humboldtforum.org/en/pages/hf-en

Stroh, W. M. (2005). Musik der einen Welt. In W. Jank (Ed.), Musik-Didaktik: Praxishandbuch für die Sekundarstufe I und II (1st ed., pp. 185-193). Cornelsen Scriptor.

Tuck, E., \& Yang, K. W. (2012). Decolonization is not a Metaphor. Decolonization: Indigeneity, Education \& Society, 1(1), 1-40. https://clas.osu.edu/sites/clas.osu.edu/files/ Tuck\%20and\%20Yang\%202012\%20Decolonization\%20is\%20not\%20a\%20metaphor.pdf

UNESCO. (2013). Basic Texts of the 2005 Convention on the Protection and Promotion of the Diversity of Cultural Expressions. http://unesdoc.unesco.org/images/0022/002253/225383E.pdf 
Van Wel, F., Couwenbergh-Soeterboek, N., Couwenbergh, C., ter Bogt, T., \& Raaijmakers, Q. (2006). Ethnicity, youth cultural participation, and cultural reproduction in the Netherlands. Poetics, 34(1), 65-82. https://doi.org/10.1016/j.poetic.2005.06.001

Wilson, N., Gross, J., \& Bull, A. (2017). Towards Cultural Democracy: Promoting Cultural Capabilities for Everyone. https://www.kcl.ac.uk/cultural/resources/reports/towards-cultural-democracy2017-kcl.pdf

Zembylas, T., \& Niederauer, M. (2017). Composing Processes and Artistic Agency: Tacit Knowledge in Composing (1st ed.). Routledge Advances in Sociology. Taylor and Francis.

Zolberg, V. L. (1997). African Legacies, American Realities: Art and Artists on the Edge. In V. L. Zolberg \& J. M. Cherbo (Eds.), Cambridge cultural social studies. Outsider art: Contesting boundaries in contemporary culture (pp. 53-70). Cambridge Univ. Press.

Zolberg, V. L., \& Cherbo, J. M. (Eds.). (1997). Cambridge cultural social studies. Outsider art: Contesting boundaries in contemporary culture. Cambridge Univ. Press. 